Filozofska fakulteta, Univerza v Ljubljani

mojca.leskovec@ff.uni-lj.si

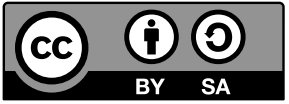

\title{
STUDIO [21]: DEUTSCH ALS FREMDSPRACHE: DAS DEUTSCHBUCH B1
}

Funk, Hermann/Kuhn, Christina/Nielsen, Laura/Winzer-Kiontke, Britta (2015): studio [21]: Deutsch als Fremdsprache: das Deutschbuch B1. Berlin: Cornelsen. ISBN: 978-306-520599-3, mehka vezava, 287 strani, 29,99€.

\section{UVOD}

Pregledani učbenik z vajami in priloženim DVD-jem z e-učbenikom prenovljene učbeniške serije studio 21 za raven B1, izdan v letu 2015 in dostopen tudi v dveh zvezkih, smiselno dopolnjujejo dodatna gradiva za pouk ter samostojno delo v tiskani in digitalni obliki, in sicer avdio- in videozgoščenka $\mathrm{k}$ učbeniškim enotam, digitalni in tiskani priročnik za učitelja, vadnica s testi, dodatna jezikovna vadnica, žepnica z besediščem, dvojezični slovarji in aplikacije za učenje besedišča, kot tudi platforma Scook (https:// www.scook.de/) s spletnimi gradivi.

Učbenik z e-gradivom studio 21 B1 je Strokovni svet Republike Slovenije za splošno izobraževanje 20. oktobra 2016 potrdil za uporabo pri nemščini kot prvem tujem jeziku v 2. letniku in kot drugem tujem jeziku v 3. in 4. letniku gimnazijskega izobraževanja ter nemščini kot prvem tujem jeziku v 3. in 4. letniku srednjega tehniškega in strokovnega izobraževanja.

\section{ZGRADBA UČNEGA GRADIVA}

Tudi v prenovljeni različici učbeniške serije studio osnovno učno sredstvo predstavlja učbenik z vajami, le da mu je sedaj priložen tudi DVD z njegovo različico v e-obliki. Tako tiskana kot digitalna oblika učbenika obsegata uvodno enoto, ki po predhodnih učbenikih za osnovno raven učenja ciljnega jezika uvaja v srednjo raven, tj. učenje za samostojno rabo, deset nadaljnjih enot, vsako z lastno temo, ter dve mednje uvrščeni dodatni enoti, t. i. postaji, namenjeni ponovitvi in poglobitvi obravnavanega v predhodnih enotah. Priložena e-knjiga, sicer prav tako dostopna prek platforme Scook, poleg 
učbenika v digitalni obliki vsebuje še avdioposnetke $\mathrm{k}$ vajam, videoposnetke za vadbo govorjenja in interaktivne vaje.

Vsaka od desetih učbeniških enot obsega skupno 16 strani, od tega osem strani obravnave nove snovi, zatem pa osem strani vaj, čemur sledita samoevalvacijski test ustnega in pisnega izražanja, besedišča, slovnice in izgovarjave ter stran s pripravo za izpit iz ciljnega jezika na ravni B1, ki vsakokrat prinaša vaje za posamezni del izpita, tj. bralno ali slušno razumevanje oz. pisno ali ustno izražanje, ter je uporabna tudi kot priprava na izpit iz nemščine na osnovni ravni slovenske splošne mature. Postaji uvaja urjenje za uporabo jezika v poklicnih situacijah, sledijo vaje za utrjevanje besedišča in slovnice predhodnih enot, nato pa videopostaja $\mathrm{z}$ vajami za razvijanje slušno-vidnega razumevanja in končno t. i. revijalni strani z raznolikimi besedilnimi vrstami.

V dodatku na zadnjih straneh učbenika najdemo primer testa za preverjanje dosežkov na ravni predelanega gradiva, sestavljenega iz nalog bralnega in slušnega razumevanja ter pisnega in ustnega izražanja, t. i. partnerske strani z dopolnjenimi podatki za delo $\mathrm{v}$ dvojicah, nadalje pregled obravnavane slovnice, seznama nepravilnih glagolov in glagolov s predlogi, besedila v okviru učbenika predvajanih posnetkov, ki niso (v celoti) natisnjena že v posameznih enotah, ter abecedni seznam $\mathrm{v}$ učbeniku uporabljenih besed s pripisano enoto in nalogo njihove prve pojavitve. Rešitve vaj učbeniku niso priložene, temveč so brezplačno dostopne prek spletne strani oz. platforme Scook.

\section{VSEBINA UČNEGA GRADIVA}

Prenovljeno učno gradivo studio 21 kot eno sedmih načel, na katerih učbeniška serija temelji, ohranja usklajenost s smernicami Skupnega evropskega jezikovnega okvira (SEJO). Tako implicitno kot eksplicitno je tudi v enote in postaji gradiva za raven B1 integrirano učenje nemščine za splošno in poklicno življenje.

Učne teme, obravnavane na predhodnih ravneh, gradivo na ravni B1 nadgrajuje in jim dodaja nove. Pri tem je deset osnovnih enot, naslovljenih Trenutki, Vsakdan, Moški - ženske - pari, Delo v spreminjanju, Šola in učenje, Podnebje in okolje, Nerodno mi je!, Rodovi, Migracija, Evropa, vsebinsko usklajenih z učnimi temami Delo in poklic, storitvene dejavnosti, Prosti čas in zabava, Politika in družba, Medčloveški odnosi, Šola in izobraževanje, Medkulturnost, Narava in varstvo okolja, Družina in stanovanje ter Literatura, priporočenimi v aktualnem učnem načrtu za pouk nemščine v gimnaziji (UN 2008). Učbeniška serija studio 21 tako na ravneh A1-B1 obravnava vse teme, ki jih učni načrt predvideva za razvijanje splošnih in sporazumevalnih zmožnosti.

Učno gradivo s ciljno skupino starejši mladostniki in odrasli uporabnika sooča z aktualnimi družbenimi temami, kot so spremembe na trgu dela, migracija, medkulturnost, podnebne spremembe, Evropska unija, a s posameznimi vsebinami, kot so film, nogomet, potovanja, šolski vsakdan v Nemčiji, študentske izmenjave, nagovarja tudi njegova mladostniška zanimanja. 


\section{RAZVIJANJE SPORAZUMEVALNIH ZMOŽNOSTI}

Celostno sporazumevalno zmožnost v nemščini uporabniki s studiem 21 na ravni B1 dosegajo z nadaljnjim razvijanjem receptivnih in produktivnih zmožnosti, tj. slušnega in bralnega razumevanja ter pisnega in ustnega izražanja, kot tudi z razvijanjem interakcije, mediacije in medkulturne zmožnosti ter specifičnih jezikovnih zmožnosti. Skladno s ciljno ravnijo učbenik posebej spodbuja interakcijo ter zmožnosti govorjenja in pisanja. Učno gradivo, ki pouk pojmuje kot razvijanje kompetenc, uporabnike širše vodi h ključni kompetenci sporazumevanje $\mathrm{v}$ tujih jezikih, poleg te pa $\mathrm{v}$ sicer različnem obsegu razvija še preostalih sedem ključnih kompetenc za vseživljenjsko učenje, pri čemer posebno pozornost namenja digitalni pismenosti in učenju učenja.

\section{METODIČNO-DIDAKTIČNI PRISTOP}

Poleg usklajenosti s smernicami dokumenta SEJO prenovljeno učno gradivo studio 21 na ravni B1 ohranja tudi preostalih šest osnovnih načel, na katerih je temeljila že učbeniška serija studio $d$, tj. poklicna usmerjenost, optimalna in prilagodljiva raba digitalnih pripomočkov, k uporabi jezika usmerjeno učenje slovnice, avtomatizacija, dosledna vadba glasoslovja, spoznavanje dežele in kulture z medkulturnim vidikom, ter jih nadgrajuje. Ponudba digitalnih vsebin je tehnično aktualizirana in vsebinsko nadgrajena, spoznavanje dežele in kulture obogateno s številčnejšimi stvarnimi besedili, fotografijami in videoposnetki nemško govorečih dežel, načelo vadenja in avtomatizacije pa dopolnjeno v skladu z novimi spoznanji metodično-didaktičnega raziskovanja.

Učno gradivo se ne osredotoča le na eno učno metodo, temveč pri izbiri izhaja iz učnih ciljev in združuje različne pristope. Učni proces je osredinjen na učenca in komunikativno usmerjen. Namesto h kopičenju vedenja o jeziku spodbuja k njegovi dejavni uporabi, pri čemer so vaje zasnovane preventivno, tj. tako, da napake bolj preprečujejo kot popravljajo in samodejno vodijo k uspehu. Vpeljava slovničnih strukur spodbuja raziskovalno učenje, vendar so jezikovne zakonitosti kljub pričakovanju uporabnikovega udejstvovanja predstavljene razumljivo, njihov končni pregled pa podaja nazoren oris jezikovnega sistema. Pri delu $\mathrm{z}$ besediščem učno gradivo skladno s spoznanji nevrodidaktike posebno pozornost namenja povezovanju informacij in ustrezni pogostnosti ponavljanja. Učbeniška serija poleg tega smiselno uporablja predhodne izkušnje z učenjem jezikov kot prednost ciljne skupine mlajši odrasli in odrasli uporabniki. 


\section{ZAKLJUČEK}

Ocenjujem, da so uporabniki po predelanem učnem gradivu skladno z opredelitvijo ravni B1 v dokumentu SEJO kot prejemniki in tvorci govorjenih in pisanih besedil s splošnimi temami v pretežno vsakdanjem jeziku usposobljeni za samostojno uporabo ciljnega jezika. Menim, da jih učno gradivo studio 21 B1 ob upoštevanju najnovejših spoznanj stroke $\mathrm{k}$ temu cilju vodi po dobro premišljeni in učinkovito načrtovani poti. 